\title{
INVESTIGATING THE SIMULTANEITY OF CORPORATE HEDGING AND DEBT POLICIES: Empirical Evidence from Indonesia*
}

\author{
Iman S. Suriawinata
}

The primary objective of this paper is to investigate the simultaneity of corporate hedging and debt policies. Using a pooled sample of Indonesian non-financial listed firms covering the periods of 19962001, the present study finds evidence that corporate hedging and debt policies are simultaneously determined. That is, the use of debts motivate firms to hedge; but simultaneously, hedging increases debt capacity and induces firms to borrowmore in order to take advantage of the tax benefits arising from additional debt capacity. Another important finding is that financially distressed firms-as indicated by their debt restructuring programs-are less motivated to hedge, because such firms will see that the option values of their equity will increase as their cash-flow volatilities increase. Therefore, financially distressed firms tend not to hedge; or at least, hedge lesser compared to those of firms that do not experiencefinancial distress.

Keywords: currency derivatives; corporate hedging policy; debt policy

* This paper is a modified version of a part of my doctoral dissertation at the University of Indonesia. I wish to thank my promotors: Prof. Dr. Prijono Tjiptoherijanto and Dr. Ruslan Prijadi for their continuous support and valuable assistance, and the chair and members of the examining committee: Prof. Dr. I.G.N. Agung, Dr. T. Sunaryo, and Dr. Indra Widjaja for their useful comments and suggestions. Nevertheless, I am solely responsible for any remaining errors or omissions. 
Gadjah Mada International Journal of Business, May-August 2005, Vol. 7, No. 2

\section{Introduction}

Anecdotal evidence shows that many Indonesian firms use foreign currency debts to finance their operation and investment activities. The interest rate difference between the foreign currency and the Rupiah denominated loans is believed to be a primary reason for employing foreign currency debts. Nevertheless, firms are quite aware that employing foreign currency debts to exploit short-term foreign exchange market inefficiencies ${ }^{1}$ will expose them to foreign currency risk which might threaten their profitability, or even perhaps their survivability. Therefore, to mitigate the currency risk associated with the use of foreign currency denominated debts, many Indonesian firms implement hedging programs with currency derivative instruments -such as currency forwards, futures, swaps, and options.

According to Modigliani-Miller's $(1958,1963)$ analysis of capital structure policy, hedging programs do not create value for the shareholders because they can omit the firm's hedging program in their analysis to suit their individual risk appetite. If this is so, then why do firms hedge? The answer lies on the fact that the ModiglianiMiller's $(1958,1963)$ analysis is based on the assumptions of perfect capital markets, symmetric information, and equal access to capital markets. Obviously, all these assumptions are violated in the real world.

Based on capital market imperfections (e.g. corporate taxes and transaction costs), financial economists have developed several theories attempting to explain what motivates firms to hedge. They argue that firms hedge in order to reduce expected tax liabilities and financial distress costs (Smith and Stulz 1985), minimize underinvestment costs (Froot et al.1993), and alleviate asset substitution problems arising from agency conflicts between shareholders and debt-holders (Culp 2001). Therefore, it is claimed that the implementation of a hedging program by a firm will create value for its shareholders through reductions in tax liabilities, financial distress costs, underinvestment costs, and agency costs. Employing a sample of 720 large US nonfinancial firms between 1990 and 1995, Allayannis and Weston (2001) find a positive relation between firm value - as proxied by Tobin's Qand the use of foreign currency derivatives. Using data from Indonesian listed non-financial firms between 1996 and 2001, Suriawinata (2004) has conducted a similar study and has also found that corporate hedging program with currency derivatives enhances firm value. However, due to difficulties in measuring Tobin's Q ratios for

\footnotetext{
${ }^{1}$ Using the Indonesian Rupiah/US dollar floating rate data from July 1997 up to July 2002, Suriawinata (2002) has obtained results unsupportive to the UIP (Uncovered Interest-rate Parity) doctrine. Therefore, the results indicate that there are opportunities to exploit interest rate differentials due to foreign exchange market inefficiencies - at least in the short term.
} 
Indonesian firms, Suriawinata (2004) employs the ratio of market-to-book value of equity as a proxy for firm value. $^{2}$

Adding to the literature of corporate hedging theories, Ross (1996) has proposed an interesting hypothesis relating to corporate hedging policy. $\mathrm{He}$ argues that while hedging reduces a firm's financial distress costs (Smith and Stulz 1985), at the same time hedging also increases the firm's debt capacity; and therefore, the firm can realize more tax benefits from the increased leverage. Because it is the existence of debts that initially motivates firms to hedge, then Ross's (1996) argument implies a simultaneous rela- tionship between corporate hedging and debt policies. Two studies on the determinants of hedging policy within the context of a simultaneous relationship with the debt policy have been conducted (Geczy et al. 1997; Graham and Rogers 2002), and the results are mixed. Employing a two-stage Logit regression model, Geczy et al. (1997) do not find a simultaneous relationship between hedging decision using currency derivatives and the level of debts. On the other hand, employing a two-stage Tobit regression model, Graham and Rogers (2002) find a positive and significant simultaneous relationship between extent of hedging using interest rate and currency de-

Figure 1. Monthly \% Change in Rupiah/US Dollar Exchange Rates January 1996 - December 2001

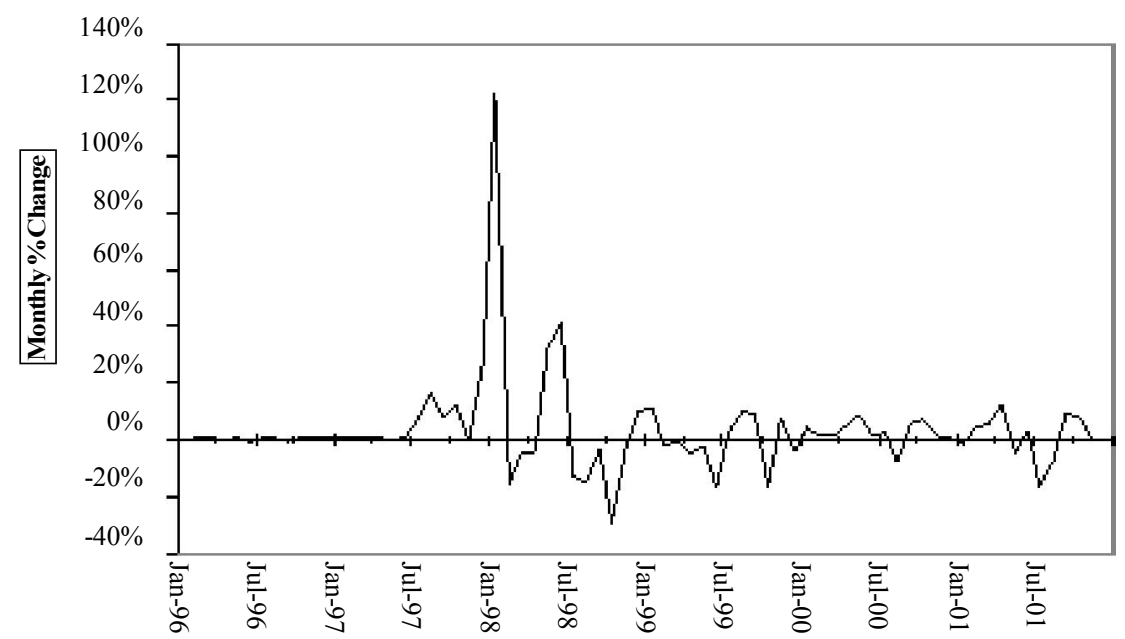

\footnotetext{
${ }^{2}$ Varaiya et al. (1987) have shown that Tobin's Q ratio and the market-to-book value of equity ratio are theoretically equivalent measures of value creation, and their findings confirm that both ratios are also empirically equivalent measures of value creation.
} 
Gadjah Mada International Journal of Business, May-August 2005, Vol. 7, No. 2

rivatives and the level of debts. Hedging decision refers to whether or not a firm hedges its financial exposure, while extent of hedging refers to how much notional amount of derivatives a firm holds to hedge.

Using data from Indonesian nonfinancial listed firms covering the periods of 1996-2001, this paper investigates the simultaneity of corporate hedging and debt policies. The present study focuses on the use of foreign currency derivatives to hedge against the foreign exchange exposure. As can be seen from Figure 1, the periods of study are mostly dominated by extremely high Rupiah/US Dollar exchange rate volatilities that have never occurred in the history of Indonesian economy. Therefore, examining firms hedging policy with currency derivatives during the periods of 1996-2001 should be interesting.

This study extends previous studies, and employs both Logit and Tobit models to investigate the simultaneity of corporate hedging and debt policies. The Logit model is used to examine the relationship between the hedging decision and the debt policy, while the Tobit model is used to examine the relationship between the extent of hedging and the debt policy. Since it is observed that many Indonesian firms restructure their debts during the periods of 1996-2001, the present study also investigates the effect of debt restructuring on corporate hedging policy.

\section{Theories of Hedging Motives and Previous Empirical Evidence}

The literature on corporate hedging motives can be sub-divided into two main streams (Tufano 1996). The first stream focuses on hedging as a means to maximize shareholder value through reductions in expected tax liabilities, expected financial distress costs, underinvestment costs, and asset substitution costs (e.g. Smith and Stulz 1985; Froot et al. 1993; Culp 2001). While the second stream focuses on hedging as a means to maximize managerial private utility (e.g. Stulz 1984; Smith and Stulz 1985; DeMarzo and Duffie 1995; Breeden and Viswanathan 1996). However, since the present study investigates the simultaneity of hedging and debt policies within the context of maximizing shareholder value, the following shall discuss only the shareholder value maximizing motives of corporate hedging activities.

\section{Shareholder Value Maximizing Motives}

Tax Incentive. Smith and Stulz (1985) show that volatility is costly when firms have convex effective tax functions; and therefore, they argue that firms hedge in order to reduce expected future tax liabilities. Convexity in corporate income tax arises from: (i) progressivity in income tax rates, (ii) tax preference treatments 
such as tax holiday, and (iii) tax loss carry-forwards. The more convex the effective tax function of a firm, the more incentive it has to hedge. As an illustration, if a firm has large tax loss carry-forwards and it does not hedge, then continued losses from currency fluctuations might prevent the firm to utilize the accumulated tax losses to compensate future income tax liabilities. ${ }^{3}$ Therefore, the tax incentive motivation for hedging predicts that hedging is positively related with tax loss carry-forwards.

Empirical evidence regarding tax incentive is unclear. For example, Nance et al. (1993) find moderate evidence that hedging firms face more convex tax functions. However, Tufano (1996) and Geczy et al. (1997) do not find supportive evidence that firms hedge in response to tax convexity. Graham and Rogers (2002) even find a negative and significant (at $1 \%$ ) relationship between corporate hedging policy and tax loss carry-forwards. This later finding contradicts the taxbased motivation for hedging.

Expected Costs of Financial Distress. According to Smith and Stulz (1985), hedging reduces the likelihood of financial distress or bankruptcy, and therefore it enhances the value of the firm. This increase in firm value arises from the reduction in cash flow volatility which minimizes the number of states that the hedging firm experi- ences financial difficulty (Nguyen and Faff 2002).

Many studies use debt ratio as an indicator of the likelihood of financial distress to measure expected distress costs. Higher debt ratio indicates higher expected financial distress costs. Therefore, it is predicted that the relationship between debt ratio and corporate hedging policy will be positive.

Previous empirical evidence regarding financial distress cost hypothesis is also mixed. Nance et al. (1993) find a positive but not significant relationship between debt ratio and corporate hedging decision. On the other hand, Geczy et al. (1997) find a negative but not significant relationship between debt ratio and hedging decision. However, later studies by Graham and Rogers (2002) and Nguyen and Faff (2002) find positive and significant relationships between leverage and corporate hedging policy.

Underinvestment Costs. According to Froot et al. (1993), costly external financing is a capital market imperfection that makes hedging a valueenhancing strategy. Based on pecking order hypothesis (Myers and Majluf 1984) on preference of financing sources, Froot et al. (1993) argue that underinvestment costs arise if firms find that external financing-either debt or equity- are sufficiently expensive that firms must reduce their investment spending during times when in-

\footnotetext{
${ }^{3}$ Based on the Indonesian tax laws, a firm can compensate (that is to carry-forward) its current tax losses against future tax liabilities up until five years.
} 
Gadjah Mada International Journal of Business, May-August 2005, Vol. 7, No. 2

ternally generated cash-flows are not sufficient to finance growth opportunities. The underinvestment costs represent the foregone projects' net present values that would otherwise accrue to them should the internal funds were available to finance the projects. With hedging, firms are protected from cashflow volatilities, and therefore are ensured that sufficient internally generated cash will be available to take advantage of profitable investment opportunities.

Using different proxies for investment opportunities -e.g. R\&D expenditures, market-to-book value of equity, and book-to-market value of equity- several studies have empirically examined the underinvestment cost hypothesis (Nance et al. 1993; Geczy et al. 1997; Gay and Nam 1998; Haushalter 2000; Graham and Rogers 2002; Nguyen and Faff 2002). Most of those studies find evidence of a positive and significant relationship between a firm's hedging activity using derivatives and its investment opportunities.

Asset Substitution Costs. Culp (2001) asserts that asset substitution costs arise because of the different incentives faced by equity and debt holders to take on certain investment projects. In the presence of debt fi- nancing, shareholders are motivated to select riskier projects than debtholders are comfortable with. ${ }^{4}$ However, debt-holders recognize this opportunistic risk-shifting behavior on the part of shareholders, and therefore they impose costly debt covenants for monitoring purposes and they usually charge higher lending rates to the projects. Ostensibly, increased cost of capital will reduce the net present value of the projects. This reduction in the projects' NPVs represents the asset substitution costs arising from the shareholders' action of substituting less risky projects with those of riskier ones. However, asset substitution costs could be substantially reduced for firms that hedge their projects' cash-flows. When cash-flows of debt-funded projects are well-hedged, debt-holders would be satisfied with less lending rates compared to those of firms who do not hedge. With a lower cost of capital, the pro-ject's net present value will increase, and so is the shareholders' wealth.

Lookman (2005) examines the role of hedging in mitigating the asset substitution problem arising from the use of bank debt by oil and gas firms in the United States. Using a sample of US oil and gas producers for the periods of 1999-2000, he finds that firms

\footnotetext{
${ }^{4}$ This follows Jensen and Meckling (1976) who argued that in the presence of debt, shareholders have a convex claim on a firm's assets; and therefore, have incentives to increase, rather than decrease, firm risk. In other words, shareholders transfer part of the risk to the debt-holders. That is, if the project is successful, shareholders will reap most of the benefits; while if it is unsuccessful, debt-holders will bear part of the losses. Additionally, this risk-shifting problem will be more acute in firms with extremely high leverage.
} 
with bank debt hedge their exposures to commodity price risk.

Simultaneity of Corporate Hedging and Debt Policies Stulz (1996), Ross (1996), and Leland (1998) argue that debt financing motivates firms to hedge, because hedging reduces cashflow volatility, and therefore decreases the probability of bankruptcy and financial distress. Reductions in the financial distress costs due to hedging will increase the firms' debt capacity (Ross 1996); and since there are tax benefits from debt financing, firms will be induced to borrow more to take advantage of the potential additional tax benefits. However, increased debt will further increase the likelihood of financial distress -and thus, firms will hedge more to mitigate the increased distress probability. In short, the above analysis suggests that there is a simultaneous relationship between hedging and debt policies; that is- hedging increases debt capacity, and simultaneously debt affects hedging policy.

In fact, building on the trade-off theory of capital structure (Castanias 1993), a reduction in the financial distress costs will lead to a greater optimal leverage; and hence, more tax benefits. Ross (1996) has demonstrated that hedging can result in an enhanced optimal capital structure, worth an additional value of approximately 10-15 percent for shareholders.

Two studies are known to have examined the simultaneous relationship between corporate hedging and debt policies, where both studies adopt a two-stage estimation technique to control for the simultaneity of the two policies. Using a Logit regression model, Geczy et al. (1997) do not find significant relationship between the debt policy and hedging decision. However, by employing a Tobit regression model, Graham and Rogers (2002) have found that hedging increases debt capacity, and simultaneously debt also affects hedging policy. Using simultaneous system of equations, Graham and Rogers (2002) test whether the extent of hedging affects the debt ratio, while Geczy et al. (1997) test whether the probability of hedging affects the debt ratio. With their findings, Graham and Rogers (2002) claim that it is not the yes/no decision of whether to hedge, but rather how much a firm hedges, that affects the level of debts.

\section{Methodology}

\section{Samples}

The initial sample includes all Indonesian non-financial firms listed in the Jakarta Stock Exchange in any year within the periods of 1996-2001. However, to be included in the final sample, a firm must:

(i) have a complete set of audited financial statements including the notes to financial statements,

(ii) have a foreign currency exposure arising from imported raw materials, export sales, assets or liabilities in foreign currencies, or have foreign subsidiaries, 
(iii) have an adequate disclosure on foreign currency liabilities,

(iv) maintain accounting records in Rupiah currency, and

(v) have a positive book value of equity at year end.

Imposing these criteria yields a total of 1007 firm-year observations from 229 firms. ${ }^{\mathbf{5}}$ Information about corporate hedging with foreign currency derivatives is obtained from notes to financial statements where it is found that 245 firm-year observations report foreign currency derivatives usage such as currency forwards, futures, swaps, and options. However, only 225 firm-year observations report the notional amount of foreign currency derivatives held. ${ }^{6}$ All cross-sectional units ( $N$ firms) are pooled by year ( $T$ years), and multiple regression analyses are then applied to the pooled data to investigate the simultaneity of the corporate hedging and the capital structure policies. Hence, the present study employs a data structure called pooled cross sections over time. ${ }^{7}$ Following Wooldridge (2002), this approach assumes that every year a new random sample is taken from the relevant population. ${ }^{8}$ However, to control the time effects, the present study includes year dummies in its multiple regression models, where the year 1996 is used as the basis or benchmark year. ${ }^{9}$

\section{Hypothesis and Empirical Model}

Following Ross (1996), it is hypothesized that corporate hedging and debt policies are simultaneously de-

\footnotetext{
${ }^{5}$ Firms do not have equal number of observations due to new listing, delisting, or failing to meet the sampling criteria in certain years.

${ }^{6}$ Prior to the stipulation of PSAK No. 59 Tahun 1999 which obliges firms to report their derivatives holdings, disclosure of derivatives usage is voluntary. Although many sample firms disclose the notional amount of their derivatives holdings, yet there are some firms that report the usage of currency derivatives but not the notional amount. All firms in the sample state that they hold foreign currency derivatives to hedge against foreign exchange exposure.

${ }^{7}$ An alternative approach is to use a panel data set up, where the same sample firms are followed over time, and the data will be structured in blocks of observation, either of $\mathrm{T}$ for a given firm $\mathrm{i}$ or $\mathrm{N}$ for a given year t. However, since firms do not have equal number of observations, then an unbalanced panel data is obtained. While estimating an unbalanced panel data is possible (Green 2002, 2003), it also introduces an attrition bias which is rather complicated to handle (Wooldridge 2002). On the other hand, imposing a balanced panel data would significantly reduce the sample size.

To avoid the loss of many valuable information on firms' hedging activities, a pooled data approach with some restrictive assumptions is applied. Therefore, the results of this study should be interpreted by taking into account those restrictive assumptions.

${ }^{8}$ If sample firms appear more than one time period, their recurrence are treated as coincidental and ignored. In short, if a sample firm does appear in each and every year during the periods of 1996-2001, then the observations will be regarded as 6 different and independent firms. Wooldridge (2002) provides good discussion that contrasts the pooling of cross section over time approach with that of the panel data.

${ }^{9}$ The use of year dummies is basically similar to conducting the Chow test on the pooled data (see Gujarati 2003: 306-310).
} 
termined. To examine the simultaneity of corporate hedging and debt policies, the present study constructs a system of structural equations consisting of hedging policy equation and debt policy equation. The present study follows both Geczy et al. (1997) and Graham and Rogers (2002) methodologies in investigating the simultaneity of corporate hedging and debt policies, and therefore uses both Logit and Tobit regression models to examine corporate hedging policy. The Logit regression is used to examine the hedging decision (yes/no decision), while the Tobit regression is used to examine the extent of hedging. ${ }^{10}$

The debt specification used by the present study adopts explanatory variables suggested by Titman and Wessels (1988), Geczy et al. (1997), and Hovakimian et al. (2001). Following Geczy et al. (1997) and Graham and Rogers (2002), the debt equation is estimated by using the OLS method.

\section{Corporate Hedging Policy}

The present study develops two hedging policy multiple regressions: the Logit regression to estimate the hedging decision equation, and the Tobit regression to estimate the extent of hedging equation. As the dependent variables, the study employs two measures of corporate hedging policy (HEDGING) variables, i.e.: (i) dummy hedging ( $\left.D \_H E D G E\right)$ to represent the decision to hedge in the Logit regres- sion, and (ii) the total notional amount of foreign currency derivatives contract divided by total assets (TOT_HEDGE) to represent the extent of hedging in the Tobit regression.

The followings list the various independent variables used in the Logit and Tobit regressions and describe their hypothesized relationships with the dependent variables $(D H E D G E$ and TOT HEDGE) of each regression. Leverage (DEBT MVE) is the independent variable of interest, while other independent variables act as control variables.

(a) Tax-Loss Carry Forward (TAXLOSS): Firms hedge in order to reduce expected tax liabilities, and the more convex the tax schedule is, the larger the incentive for firms to hedge. The present study uses tax-loss carry forwards divided by market value of equity to proxy tax incentive, and predicts a positive relationship between taxloss carry forwards and corporate hedging policy.

(b) Leverage (DEBT_MVE): Firms hedge in order to reduce expected costs of financial distress and bankruptcy. Higher leverage indicates higher expected costs of distress, and therefore it is predicted that higher leverage will lead to more incentive to hedge. Leverage is proxied by total interest-bearing debt divided by the market value of equity.

\footnotetext{
${ }^{10}$ The Tobit model is used because the extent of hedging (represented by the notional amount of currency derivatives holding divided by total assets) is censored at zero.
} 
Gadjah Mada International Journal of Business, May-August 2005, Vol. 7, No. 2

(c) Investment Opportunities (BME): Froot et al. (1993) argue that firms that have potential investment opportunities will be motivated to hedge to ensure the availability of internal cash-flows to fund future investments. On the other hand, firms with no growth opportunities will be less motivated to hedge. Similar to Nance et al. (1993), Geczy et al. (1997) and Graham and Rogers (2002), this study uses book-to-market value of equity ratio as a proxy for growth opportunities. Larger book-to-market value of equity ratio means lesser growth opportunities. Therefore, this study predicts a negative relationship between the book-to-market value of equity ratio with corporate hedging policy.

(d) Business Risk (V_ROA): This study employs volatility of return on assets -defined as the volatility of EBIT to total assets- as a measure of business risk. Higher business risk implies higher asset substitution costs, and it is predicted that volatility of return on assets is positively related with corporate hedging policy.

(e) Liquidity (LIQUID_TL): Firms may use substitutes for hedging to manage risk. For example, firms with more liquid assets will be less likely to face financial distress (Geczy et al. 1997). Therefore, it is predicted that liquid assets are negatively related with corporate hedging policy. The present study uses the ratio of liquid assets ${ }^{11}$ to total liabilities as a proxy for hedging substitute.

(f) Foreign Exchange Exposure (FCL_TA ): Obviously, firms hold currency derivatives to hedge against foreign exchange exposure. This study uses the ratio of foreign currency denominated liabilities divided by total assets to proxy foreign exchange exposure, and predicts a positive relationship between foreign exchange exposure with corporate hedging policy.

(g) Firm Size (SIZE_TA): Previous empirical studies provide evidence that firm size is positively related with corporate hedging policy, indicating the existence of economies of scale in hedging costs (Nance et al. 1993; Mian 1996; Geczy et al. 1997; Graham and Rogers 2002). Similar to past research, this study uses natural logarithm of total assets as a proxy of firm size, and predicts a positive relationship between firm size and corporate hedging policy.

(h) Debt Restructuring (D_RES TRU): The existence of debt restructuring indicates severe financial distress. It is well known that the option value of equity increases as the probability of financial dis-

\footnotetext{
${ }^{11}$ In this study, liquid assets consisted of: cash and cash equivalents, trade receivables, and note receivables.
} 
tress increases. Because the option value of equity of distressed firms will increase as cash-flows volatility increases, then it would be for the best interest of such firms if they do not hedge. ${ }^{12}$ The present study uses a dummy variable for debt restructuring; that is a firm will be assigned a value of 1 if it is restructuring its debt, and 0 otherwise. It is predicted that debt restructuring is negatively related with corporate hedging policy.

(i) Interaction Variables: To account for any interaction effects, the present study includes two interaction variables, i.e. D_RESTRU* DEBT_MVE and D_RESTRU* $S I Z E_{-} T A$ in the corporate hedging policy equations. However, the present study does not provide any prediction on the directions of the relationships between the interaction variables and corporate hedging policy.

\section{Debt Policy Equation}

The dependent variable of the debt policy equation is the total interestbearing debt divided by the market value of equity. The two measures of corporate hedging policy (i.e. $D \_H E D G E$ and TOT_HEDGE) are the independent variables of interest, while other independent variables act as control variables. The list of all independent variables and their hypothesized relationships with the dependent variable are as follows:

(a) Hedging (D_HEDGE or TOT_HEDGE): Ross (1996) asserts that hedging increases debt capacity. Therefore, it is predicted that hedging using foreign currency derivatives is positively related with debt.

(b) Selling and General Administration Expenses (SGA): Adopting Titman and Wessels (1988), SGA represents firm uniqueness. Since uniqueness is negatively related with leverage, the present study predicts a negative relationship between $S G A$ and debt.

(c) Growth opportunities (BME): According to Titman and Wessels (1988), growth opportunities are capital assets that add value to a firm but cannot be collateralized. Firms with high growth opportunities are expected to have less debt, and vice versa. Higher book-tomarket value of equity $(B M E)$ means lower growth opportunities; therefore, the present study predicts a positive relationship be-

\footnotetext{
${ }^{12}$ Hedging reduces volatility, and based on Black and Scholes (1973) option pricing formula, a reduction in the volatility of the value of underlying asset decreases the option value. Total asset is the underlying asset, while debt is the exercise price. Debt restructuring implies that total asset is potentially insufficient to pay debt, therefore it would be better for shareholders of a distressed firm to expose their firm's assets to currency fluctuations to increase the probability that total assets will exceed debt at maturity. If this is the case, then shareholders would keep the firm; otherwise, shareholders would lose nothing as their firm is already at the mercy of debt-holders.
} 
tween the book-to-market value of equity and debt.

(d) Profitability (ROA): Following Myers and Majluf (1984), firms with higher profitability will be relying less on debt to finance their investment activities. Therefore, it is predicted that profitability is negatively related with leverage. The present study uses return on assets - measured by EBIT divided by total assets- as a proxy for profitability.

(e) Firm Size (SIZE_TA): Titman and Wessel (1988) state that large firms tend to be more diversified and less prone to bankruptcy. Therefore, larger firms are predicted to be highly leveraged. In this study, firm size is proxied by natural logarithm of total assets.

(f) Asset Tangibility (TANG): Asset tangibility affects the amount of debt that could be obtained by a firm because creditors generally rely on tangible assets as debt collaterals. The present study uses the ratio of net fixed asset-to-market value of equity as a proxy for asset tangibility, and predicts a positive relationship between asset tangibility and debt levels.

(g) Debt Restructuring (D_RES TRU): The present study argues that firms that restructure their debts must already have relatively much higher debt ratios, otherwise such firms would not embark debt restructuring programs. Therefore, the present study predicts a positive relationship between the occurrence of debt restructuring (dummy debt restructuring) and debt levels.

Previous discussions suggest that hedging can increase debt capacity, and simultaneously debt can affect hedging policy. Therefore, following Geczy, Minton, and Schrand (1997) and Graham and Rogers (2002), to investigate the simultaneity of the hedging decision and the debt policy, this study employs a two-stage estimation technique on the structural equations which consisted of: corporate hedging policy equation (Logit and Tobit Regressions):

$$
\begin{aligned}
& \text { HEDGING }_{\mathrm{it}}=\alpha_{1}+\sum_{\mathrm{j}=1997}^{2001} \delta_{\mathrm{j}} \mathrm{D}_{-} \mathrm{YR}_{\mathrm{j}}+ \\
& \beta_{1} \text { TAXLOSS }_{\text {it }}+ \\
& \beta_{2} \text { DEBT_MVF }_{\text {it }}+ \\
& \beta_{3} \mathrm{BME}_{\mathrm{it}}+\beta_{4} \mathrm{~V}_{-} \mathrm{ROA}_{\mathrm{it}}+ \\
& \beta_{5} \text { LIQUID_TL }_{\mathrm{it}}+ \\
& \beta_{6} \mathrm{FCL}_{-} \mathrm{TA}_{\mathrm{it}}+ \\
& \beta_{7} \text { SIZE_TA }_{\text {it }}+ \\
& \beta_{8} \mathrm{D} \_R E S T R U_{\mathrm{it}}+ \\
& \beta_{9} \mathrm{D}_{-} \operatorname{RESTRU}_{\mathrm{it}} \text { * } \\
& \text { DEBT_MVF }_{\text {it }}+ \\
& \beta_{10} \mathrm{D}_{-} \operatorname{RESTRU} \mathrm{it}_{\mathrm{it}} \text { * } \\
& \text { SIZE_TA }{ }_{\text {it }}+\varepsilon_{\text {it }} \ldots \ldots \ldots . .(1)
\end{aligned}
$$

Debt policy equation (OLS Regression): 
Suriawinata-Investigating the Simultaneity ofCorporateHedging and Debt Policies

Table 1. The Hypothesized Relationships between the Dependent Variables and the Independent Variables of the Corporate Hedging and the Debt Policies

\begin{tabular}{|c|c|c|}
\hline \multirow[b]{2}{*}{ Independent Variables } & $\begin{array}{c}\text { Hedging } \\
\text { Policy }\end{array}$ & $\begin{array}{l}\text { Debt } \\
\text { Policy }\end{array}$ \\
\hline & \multicolumn{2}{|c|}{ Dependent Variables } \\
\hline & $\begin{array}{c}\text { D_HEDGE }\{1,0\} \\
\text { and } \\
\text { TOT_HEDGE }\end{array}$ & DEBT_MVE \\
\hline Tax Loss Carry-Forwards (TAXLOSS) & + & \\
\hline Predicted Value of Debt Ratio (DEBT_MVF) & + & \\
\hline Book-to-Market Value of Equity $(B M E)$ & - & + \\
\hline Volatility of Return on Assets $\left(V \_R O A\right)$ & + & \\
\hline Hedging Substitute (LIQUID_TL) & - & \\
\hline Debt Restructurization $\left(D \_R E S T R U\right)\{1,0\}$ & - & + \\
\hline Foreign Currency Liabilities-to-Total Assets $\left(F C L \_T A\right)$ & + & \\
\hline
\end{tabular}

$$
\begin{aligned}
\text { DEBT_MVE } & =\phi_{1}+\sum_{\mathrm{j}=1997}^{2001} \lambda_{\mathrm{j}} \mathrm{D}_{-} \mathrm{YR}_{\mathrm{j}}+ \\
& \gamma_{1} \mathrm{HEDGINGF}_{\mathrm{it}}+ \\
& \gamma_{2} \mathrm{SGA}_{\mathrm{it}}+\gamma_{3} \mathrm{BME}_{\mathrm{it}}+ \\
& \gamma_{4} \mathrm{ROA}_{\mathrm{it}}+\gamma_{5} \mathrm{SIZE}_{-} \mathrm{TA}_{\mathrm{it}}+ \\
& \gamma_{7} \mathrm{TANG}_{\mathrm{it}}+ \\
& \gamma_{8} \mathrm{D}_{-} \mathrm{RESTRU}_{\mathrm{it}}+\varepsilon_{\mathrm{it}} \ldots \text { (2) }
\end{aligned}
$$

The multiple regression in Equation (1) are estimated using two methods, i.e. (i) the Logit method to examine the hedging decision, and (ii) the Tobit method to examine the extent of hedging. For the Logit regression, $H E D G I N G$ is a binary variable, where it will be assigned a value of $1\left(D_{-}\right.$
$H E D G E=1$ ) if an examination on the notes to financial statements reveals that the firm uses any currency derivatives such as forwards, futures, swaps or options for hedging purposes; and will be assigned a value of $0(D$ $H E D G E=0)$ otherwise. In the Tobit regression, HEDGING is the extent of hedging(represented by TOT_HEDGE -defined as the notional amount of foreign currency derivatives holding divided by total assets) and is censored at zero.

It must be noted that the above equations are the second-stage equations; where $D E B T \_M V F$ is the predicted value of the debt ratio obtained from the first-stage estimation of the debt policy equation, and $H E D G I N G F$ 
Gadjah Mada International Journal of Business, May-August 2005, Vol. 7, No. 2

is the predicted value of $D H E D G E$ and TOT HEDGE from the first-stage estimation of the hedging decision equation (Logit regression) and the extent of hedging equation (Tobit regression) respectively. The present study assumes constant coefficients over time, but different intercept for each year. ${ }^{13}$ To account for year effects, dummy years (D_YR97 up to D_YR01) are included in both corporate hedging and debt equations, where the year 1996 is used as a basis or benchmark year. ${ }^{14}$ Table 1 summarizes the hypothesized relationships between the dependent variables and the independent variables for both hedging and debt equations.

\section{Results}

Table 2 reports correlations among the independent variables of both hedging and debt equations. Of particular interest is the positive and significant correlation between corporate hedging policy ( $D \_H E D G E$ and TOT $H E D G E)$ and firm size (SIZE TA), indicating the importance of firm size in corporate hedging policy. Also, it can be seen that corporate hedging policy is negatively correlated with debt restructuring ( $D$ RESTRU), which implies that distressed firms are less motivated to hedge because the option values of their equity will increase as volatility increases. Therefore, such firms will be better-off without hedging. Another interesting observation is the negative correlation between profitability $(R O A)$ and debt restructuring ( $D R E S T R U)$. This means that profitable firms are less likely to restructure their debts.

From Table 2, it can also be observed that there is no correlation coefficient that exceeds 0.8 . As a rule of thumb, for a model involving only two independent variables, a correlation coefficient in excess of 0.8 may suggest a serious collinearity problem (Judge et al. 1988; Gujarati 2003). However, the rule will not provide a reliable guide if the model involves more than two independent variables, as in the case with the present study. Therefore, a more reliable diagnostic tool called Variance Inflating Factor (VIF) should be consulted. Table 3

\footnotetext{
${ }^{13}$ Since it has been assumed that each observation represents a different and independent unit (see Note 8), no additional assumptions are needed about the intercept and coefficient of each cross sectional unit.

${ }^{14}$ To avoid the dummy variable trap, a dummy is assigned only for each year covering 1997 to 2001 , whereas the year 1996 is used as the base or benchmark year. Therefore, the intercept $a_{1}$ and $j_{1}$ represents the mean value of the benchmark category-that is the year 1996-for equations (1) and (2) respectively. The coefficients $\left(d_{j}\right.$ and $\left.1_{j}\right)$ associated with each $D_{-} Y_{R_{j}}$ are the differential intercept coefficients, and they show by how much the value of the intercept for each year $j$ (year 1997 up to 2001) differs from the intercept coefficient of the benchmark year (i.e. year 1996).
} 
Suriawinata-Investigating the Simultaneity ofCorporateHedging and Debt Policies

Table 2. Pearson Correlations - Independent Variables

Panel A-Corporate Hedging Policy Equation

\begin{tabular}{|c|c|c|c|c|c|c|c|c|}
\hline & TAXLOSS & DEBT_MVE & BME & V_ROA & LIQ_TL & FCL_TA & SIZE_TA & D_RESTRU \\
\hline TAXLOSS & -1.000 & $-0.267 * *$ & $-0.214 * *$ & -0.045 & -0.051 & $-0.250 * *$ & * $-0.086 * *$ & $-0.343 * *$ \\
\hline DEBT_MVE & & -1.000 & $-0.282 * *$ & -0.040 & $-0.070 *$ & $-0.277 * *$ & $*-0.099 * *$ & $-0.191 * *$ \\
\hline $\mathrm{BME}^{-}$ & & & -1.000 & -0.034 & -0.057 & -0.020 & -0.045 & -0.041 \\
\hline V_ROA & & & & -1.000 & $-0.073 *$ & $-0.096 * *$ & * $-0.217 * *$ & $-0.145^{* *}$ \\
\hline$\overline{L I Q}$ LL & & & & & -1.000 & $-0.198 * *$ & $*-0.145 * *$ & $-0.138 * *$ \\
\hline FCL_TA & & & & & & -1.000 & $-0.266 * *$ & $-0.359 * *$ \\
\hline SIZE_TA & & & & & & & -1.000 & $-0.262 * *$ \\
\hline D RESTRU & & & & & & & & -1.000 \\
\hline
\end{tabular}

Panel B-Debt Policy Equation

\begin{tabular}{|c|c|c|c|c|c|c|c|c|}
\hline & D_HEDGE & TOT_HEDGE & SGA & BME & ROA & SIZE_TA & TANG & D_RESTRU \\
\hline D_HEDGE & -1.000 & $-0.652 * *$ & -0.030 & -0.060 & -0.014 & $-0.293 * *$ & -0.020 & $-0.128 * *$ \\
\hline TOT_HEDGE & & -1.000 & -0.012 & -0.016 & -0.039 & $-0.193 * *$ & $-0.078 *$ & $-0.090 * *$ \\
\hline SGA & & & -1.000 & $-0.131 * *$ & $-0.116 * *$ & $-0.240 * *$ & $-0.183 * *$ & $-0.184 * *$ \\
\hline BME & & & & -1.000 & $-0.093 * *$ & -0.045 & $-0.489 * *$ & -0.041 \\
\hline ROA & & & & & -1.000 & -0.006 & $-0.159 * *$ & $-0.172 * *$ \\
\hline SIZE_TA & & & & & & -1.000 & $-0.180 * *$ & $-0.262 * *$ \\
\hline TANG & & & & & & & $-1.000-$ & $-0.251 * *$ \\
\hline D_RESTRU & & & & & & & & -1.000 \\
\hline
\end{tabular}

**, * Significant respectively under 1 percent, and under 5 percent

reports the values of the VIF for all the independent variables, and none indicates any presence of a serious multicollinearity problem. ${ }^{15}$

Table 4 presents the results of the simultaneous equations analysis of corporate hedging and debt policies relating to both the hedging decision and the extent of hedging. Panel A reports the estimated coefficients of the hedging policy equations, while Panel B reports those of the debt policy equations. As mentioned above, a two-stage estimation technique is employed for the simultaneous equations analysis. In the first stage, both hedging policy regression and debt policy regression are performed ${ }^{16}$ to obtain the predicted values of the corporate hedging variables (D HEDGEF and TOT $H E D G E F)$ and the predicted value of debt-to-market value of equity ratio

\footnotetext{
${ }^{15}$ Variance Inflating Factor (VIF) measures the effect of the intercorrelation of the independent variables on the variances of the regression coefficient estimators. As a general rule, if the VIF of a variable exceeds 10 , then the variable is said to be highly collinear (Gujarati 2003); though there are others who suggest 30 or 40 as a benchmark value (Greene 2003).

${ }^{16}$ To save space, the results of the first-stage regression are not reported here.
} 
Gadjah Mada International Journal of Business, May-August 2005, Vol. 7, No. 2

Table 3. Variance Inflating Factors (VIF)

\begin{tabular}{|c|c|c|c|c|}
\hline \multicolumn{2}{|c|}{ Panel A - Corporate Hedging Policy Equation } & \multicolumn{3}{|c|}{ Panel B - Debt Policy Equation } \\
\hline $\begin{array}{l}\text { Independent } \\
\text { Variable }\end{array}$ & $\begin{array}{c}\text { Variance } \\
\text { Inflating Factor }\end{array}$ & $\begin{array}{l}\text { Independent } \\
\text { Variable }\end{array}$ & $\begin{array}{c}\text { Variance } \\
\text { Inflating Factor } \\
\text { (Hedging Decision) }\end{array}$ & $\begin{array}{c}\text { Variance } \\
\text { Inflating Factor } \\
\text { (Extent of Hedging) }\end{array}$ \\
\hline TAXLOSS & 1.23879 & D_HEDGE & 1.16320 & - \\
\hline DEBT_MVE & 1.21743 & TOT_HEDGE & - & 1.07644 \\
\hline BME & 1.13371 & SGA & 1.12078 & 1.11386 \\
\hline V_ROA & 1.06229 & BME & 1.36613 & 1.36614 \\
\hline LIQ_TL & 1.06027 & ROA & 1.06053 & 1.06351 \\
\hline FCL_TA & 1.29642 & SIZE_TA & 1.31664 & 1.22026 \\
\hline SIZE_TA & 1.16566 & TANG & 1.47787 & 1.48677 \\
\hline D_RESTTRU & 1.30671 & D_RESTRU & 1.22417 & 1.20112 \\
\hline
\end{tabular}

Table 4. Simultaneous Equations Analysis of Corporate Hedging and Debt Policies - Pooled Data

\begin{tabular}{|c|c|c|c|c|c|}
\hline \multicolumn{6}{|c|}{ Panel A. Corporate Hedging PolicyEquation } \\
\hline \multirow[t]{3}{*}{ Independent Variables } & \multirow[t]{3}{*}{$\begin{array}{c}\text { Predicted } \\
\text { Sign } \\
\end{array}$} & \multicolumn{2}{|c|}{$\begin{array}{l}\text { LOGIT Regression } \\
\text { (Decision to Hedge) }\end{array}$} & \multicolumn{2}{|c|}{$\begin{array}{l}\text { TOBIT Regression } \\
\text { (Extent of Hedging) }\end{array}$} \\
\hline & & $\begin{array}{c}\text { Coefficient } \\
\text { Estimate }\end{array}$ & (p-value) & $\begin{array}{c}\text { Coefficient } \\
\text { Estimate }\end{array}$ & (p-value) \\
\hline & & \multicolumn{2}{|c|}{$\begin{array}{c}\text { Dependent Variable: } \\
D_{-} H E D G E\{1,0\}\end{array}$} & \multicolumn{2}{|c|}{$\begin{array}{c}\text { DependentVariable: } \\
\text { TOT_HEDGE }\end{array}$} \\
\hline INTERCEPT & $?$ & -12.6826 & $0.0000 * * *$ & -1.7113 & $0.0000 * * *$ \\
\hline D_YR97 & $?$ & 0.3112 & 0.2214 & 0.1144 & $0.0089 * * *$ \\
\hline D_YR98 & $?$ & -0.7330 & $0.0233 * *$ & -0.0522 & 0.3480 \\
\hline D_YR99 & $?$ & -0.1947 & 0.5506 & -0.0399 & 0.4932 \\
\hline D_YR00 & $?$ & -1.0718 & $0.0021 * * *$ & -0.1847 & $0.0048 * * *$ \\
\hline D_YR01 & $?$ & -0.8612 & $0.0129 * *$ & -0.1407 & $0.0285 * *$ \\
\hline TĀXLOSS & + & -7.6965 & $0.0112 * *$ & -4.3347 & $0.0004 * * *$ \\
\hline DEBT_MVF & + & 1.8070 & $0.0056 * * *$ & 0.2123 & $0.0013 * * *$ \\
\hline $\mathrm{BME}^{-}$ & - & -2.6188 & $0.0118 * *$ & -0.4305 & $0.0017 * * *$ \\
\hline V_ROA & + & 3.1453 & $0.0158 * *$ & 0.3148 & 0.2995 \\
\hline LIQUID_TL & - & -0.2197 & 0.1214 & -0.0432 & 0.1122 \\
\hline FCL_TA & + & 1.1384 & $0.0038 * * *$ & 0.2817 & $0.0000 * * *$ \\
\hline SIZE_TA & + & 0.5719 & $0.0000 * * *$ & 0.0727 & $0.0000 * * *$ \\
\hline D_RESTRU $\{1,0\}$ & - & -12.0639 & $0.0062 * * *$ & -2.9284 & $0.0004 * * *$ \\
\hline D_RESTRU*DEBT_MVF & $?$ & -1.2624 & $0.0545 *$ & 0.0983 & 0.2204 \\
\hline D_RESTRU*SIZE_TA & $?$ & 0.5282 & $0.0105 * *$ & 0.1313 & $0.0007 * * *$ \\
\hline \multicolumn{6}{|l|}{ HeteroscedasticityTerm } \\
\hline TAXLOSS & $?$ & & & 2.8535 & $0.0000 * * *$ \\
\hline
\end{tabular}


Suriawinata-Investigating the Simultaneity ofCorporate Hedging and Debt Policies

\section{Continued from Table 4}

\begin{tabular}{|c|c|c|c|c|}
\hline \multirow[t]{3}{*}{ Independent Variables } & \multirow[t]{3}{*}{$\begin{array}{l}\text { Predicted } \\
\text { Sign }\end{array}$} & \multicolumn{2}{|c|}{$\begin{array}{l}\text { LOGIT Regression } \\
\text { (Decision to Hedge) }\end{array}$} & $\begin{array}{l}\text { TOBIT Regression } \\
\text { (Extent of Hedging) }\end{array}$ \\
\hline & & $\begin{array}{l}\text { Coefficient } \\
\text { Estimate }\end{array}$ & (p-value) & $\begin{array}{l}\text { Coefficient } \\
\text { Estimate }\end{array}$ \\
\hline & & \multicolumn{2}{|c|}{$\begin{array}{c}\text { Dependent Variable: } \\
\text { D_HEDGE }\{1,0\}\end{array}$} & $\begin{array}{c}\text { Dependent Variable: } \\
\text { TOT_HEDGE }\end{array}$ \\
\hline Log Likelihood & & -426.2261 & & -287.4561 \\
\hline LR Statistic & & 265.0167 & & 279.1735 \\
\hline Probability(LR stat) & & 0.0000 & & 0.0000 \\
\hline McFaddenR-Squared & & 0.2372 & & 0.3269 \\
\hline p-value of Ljung-Box Q-st & 0 lags) 0.8150 & & & \\
\hline \multicolumn{5}{|c|}{ p-values of Chi-Square Statistic: } \\
\hline - Hosmer-Lemeshow St & & 0.8318 & & - \\
\hline - Andrews Statistic & & 0.2552 & & - \\
\hline Prediction Accuracy & & $79.34 \%$ & & - \\
\hline Number of Observations & & 1007 & & 1007 \\
\hline - Obs with Dep=0 (Non- & gers) & 762 & & 782 \\
\hline - Obs with Dep $>0$ (Hed & & 245 & & 225 \\
\hline
\end{tabular}

Panel B. Debt PolicyEquation

\begin{tabular}{|c|c|c|c|c|c|}
\hline \multirow[t]{3}{*}{ Independent Variables } & \multirow[t]{3}{*}{$\begin{array}{c}\text { Predicted } \\
\text { Sign } \\
\end{array}$} & \multicolumn{2}{|c|}{$\begin{array}{c}\text { OLS } \\
\text { Regression }\end{array}$} & \multicolumn{2}{|c|}{$\begin{array}{c}\text { OLS } \\
\text { Regression }\end{array}$} \\
\hline & & $\begin{array}{c}\text { Coefficient } \\
\text { Estimate }\end{array}$ & (p-value) & $\begin{array}{c}\text { Coefficient } \\
\text { Estimate }\end{array}$ & (p-value) \\
\hline & & \multicolumn{2}{|c|}{$\begin{array}{c}\text { Dependent Variable: } \\
D_{-} H E D G E\{1,0\}\end{array}$} & \multicolumn{2}{|c|}{$\begin{array}{c}\text { Dependent Variable: } \\
\text { TOT_HEDGE }\end{array}$} \\
\hline INTERCEPT & $?$ & 1.2108 & $0.0111 * *$ & 0.6055 & 0.1133 \\
\hline D_YR97 & $?$ & -0.0895 & 0.2154 & -0.0825 & 0.2752 \\
\hline D_YR98 & $?$ & 0.0534 & 0.5026 & 0.0005 & 0.9944 \\
\hline D_YR99 & $?$ & -0.1114 & 0.1479 & -0.1354 & 0.0757 * \\
\hline D_YR00 & $?$ & 0.0099 & 0.9048 & -0.0568 & 0.4627 \\
\hline D_YR01 & $?$ & -0.0293 & 0.7175 & -0.0944 & 0.2097 \\
\hline D_HEDGEF & + & 0.6195 & $0.0027 * * *$ & - & - \\
\hline TOT_HEDGEF & + & - & - & 1.1471 & $0.0319 * *$ \\
\hline SGA & - & 0.0139 & 0.9305 & -0.0357 & 0.8224 \\
\hline BME & + & 0.2433 & 0.1318 & 0.2006 & 0.2110 \\
\hline ROA & - & -0.1444 & 0.4548 & -0.1738 & 0.3684 \\
\hline SIZE_TA & + & 0.0654 & $0.0136 * *$ & -0.0283 & 0.1580 \\
\hline TANG & + & 0.9606 & $0.0000 * * *$ & 0.9673 & $0.0000 * * *$ \\
\hline D_RESTRU $\{1,0\}$ & + & 0.2281 & $0.0001 * * *$ & 0.1820 & $0.0011 * * *$ \\
\hline
\end{tabular}


Gadjah Mada International Journal of Business, May-August 2005, Vol. 7, No. 2

\section{Continued from Table 4}

Panel B. Debt Policy Equation (Continued)

\begin{tabular}{|c|c|c|c|c|c|}
\hline \multirow[t]{3}{*}{ Independent Variables } & \multirow[t]{3}{*}{$\begin{array}{l}\text { Predicted } \\
\text { Sign }\end{array}$} & \multicolumn{2}{|c|}{$\begin{array}{c}\text { OLS } \\
\text { Regression }\end{array}$} & \multicolumn{2}{|c|}{$\begin{array}{c}\text { OLS } \\
\text { Regression }\end{array}$} \\
\hline & & $\begin{array}{c}\text { Coefficient } \\
\text { Estimate }\end{array}$ & (p-value) & $\begin{array}{c}\text { Coefficient } \\
\text { Estimate }\end{array}$ & (p-value) \\
\hline & & \multicolumn{2}{|c|}{$\begin{array}{c}\text { DependentVariable: } \\
\text { D_HEDGE }\{1,0\}\end{array}$} & \multicolumn{2}{|c|}{$\begin{array}{c}\text { Dependent Variable: } \\
\text { TOT_HEDGE }\end{array}$} \\
\hline R-squared & & 0.3009 & & 0.2978 & \\
\hline AdjustedR-squared & & 0.2924 & & 0.2893 & \\
\hline \multicolumn{2}{|c|}{ p-value of Ljung-Box Q-stat (10 lags) 0.9910} & \multicolumn{4}{|c|}{0.9960} \\
\hline Durbin-Watson stat & & 2.0271 & & 2.0234 & \\
\hline Regression F-statistic & & 35.6504 & & 35.1300 & \\
\hline p-value of F-statistic & & 0.0000 & & 0.0000 & \\
\hline p-value of Ramsey RESET & & 0.2336 & & 0.1437 & \\
\hline p-value of White Het F-stat & & 0.8352 & & 0.8132 & \\
\hline
\end{tabular}

***, $* *, *$ Significant for respectively under 1 percent, under 5 percent and under $10 \%$

(DEBT_MVF) respectively. In the second stage, D_HEDGEF, TOT $H E D G E F$, and $\overline{D E B T} M V F$ are then used (instead of their original values) as independent variables in the debt policy regression and the hedging policy regression.

The results of the second stage regressions are presented in Table 4. However, before discussing them, it would be useful to investigate whether there are potential econometric problems that may weaken the results. The present study focuses on the potential problems of autocorrelation, heteroscedasticity, and model specification errors.

Based on Ljung-Box Q-stats (using 10 lags), no autocorrelation problems are detected for both hedging (Logit and Tobit) and debt (OLS) regression models. Panel B of Table 4 also reports that the Durbin-Watson stats for both debt (OLS) equations involving hedging decision and extent of hedging are in the neighborhood of 2 , which value indicates that there is no first-order autocorrelation in the error terms, either positive or negative (Gujarati 2003).

Even though OLS estimates are still consistent in the presence of heteroscedasticity, the conventional computed standard errors are no longer valid, which will cause conclusions from conventionally employed $t$ and $F$ tests to be misleading. White Heteroscedasticity Test is a test of the null hypothesis of no heteroscedasticity against heteroscedasticity of some unknown general form. Panel B of Table 4 reports high probability values of 
Suriawinata-Investigating the Simultaneity ofCorporateHedging and Debt Policies

Figure 2. Testing the Stability of the Coefficients of Debt Policy Equation

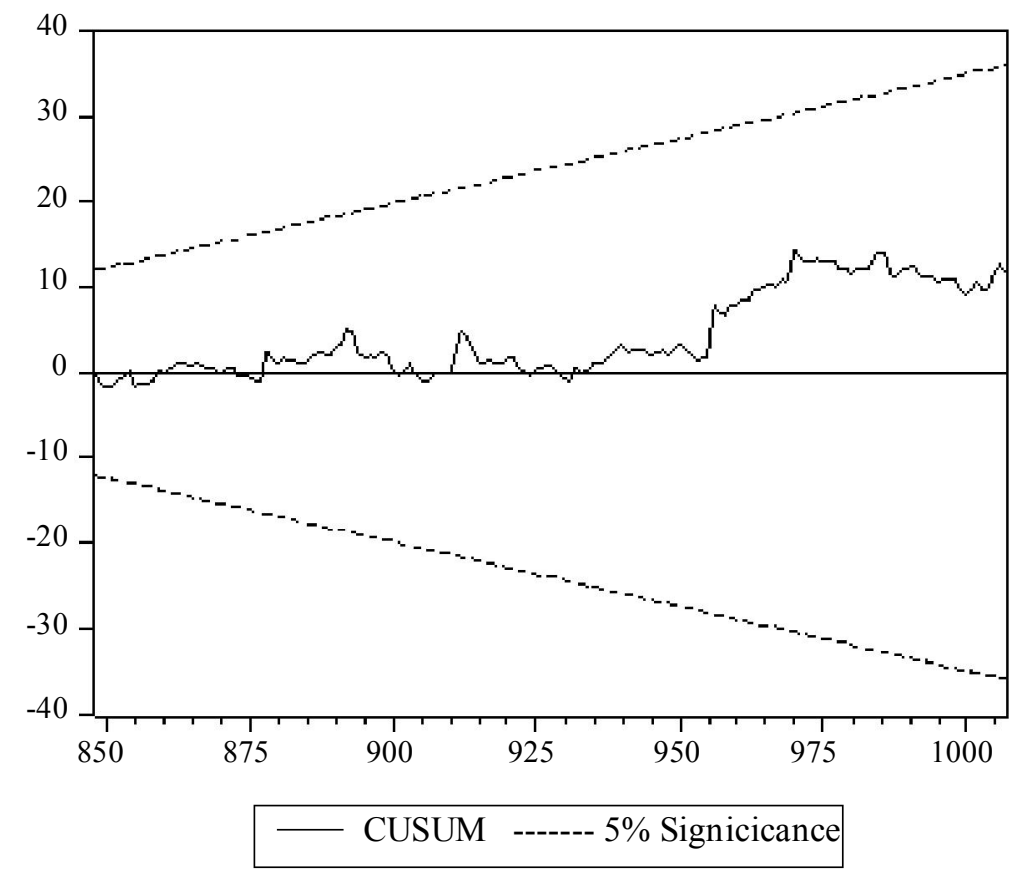

White's F-tests, which mean that the null hypothesis of no heteroscedasticity cannot berejected. Therefore, both debt specifications are homoscedastic.

Employing a Lagrange multiplier test, a multiplicative heteroscedasticity (Greene 2002) caused by TAXLOSS is found in the Tobit regression model. Therefore, the Tobit (extent of hedging) equation is estimated by correcting for the heteroscedasticity. However, by employing a similar procedure, the present study does not find any heteroscedasticity problem in the Logit (hedging decision) equation.
With regard to model specification errors, the Logit results indicate no specification errors as shown by relatively high probability values of Hosmer-Lemeshow and Andrews test statistics. For the Tobit model, the parameter estimates will be inconsistent in the presence heteroscedasticity and non-normal errors (Greene 2003, Long 1997). The problem of heteroscedasticity has been corrected and discussed in the previous paragraph, but research is still ongoing in handling the problem of non-normal errors (Greene 2002). ${ }^{17}$

${ }^{17}$ One solution is to use an alternative error distribution (Greene 2002). Employing an alternative error distribution, i.e. extreme value, the author finds that the results are more or less similar with the results that assume normal errors. However, the results are not reported here. 
Gadjah Mada International Journal of Business, May-August 2005, Vol. 7, No. 2

Panel B of Table 4 reports that the probability values of the Ramsey's RESET $F$ tests for both OLS regressions are above the significance level of 5 percent, and therefore the results indicate that both debt equations are not mis-specified. Additionally, to test the stability of the debt policy equation, a CUSUM test is conducted. As can be seen from Figure 2, the null hypothesis of coefficient stability cannot be rejected. Since the results of all the above diagnostic tests are more or less satisfactory, the followings will then discuss the results of the estimated hedging and debt policies equations.

By examining the sign (whether positive or negative) and the statistical significance of the estimated coefficients of the Logit regression, it can be said that generally the results support the view that firms hedge in order to enhance or increase shareholder value. To be more specific, it can be concluded that firms hedge in order to reduce financial distress costs $\left(D E B T \_M V F\right)$, minimize underinvestment costs $(B M E)$, and alleviate asset substitution problems $\left(V_{-} R O A\right)$. However, the results do not provide support for the tax incentive (TAXLOSS) hypothesis. Graham and Rogers (2002) argue that a significant large amount of accumulated tax losses -as in the case of many Indonesian firms during the crisis periods-represents financial distress rather than future potential tax

Figure 3. The Effect of Debt Restructuring on the Estimated Probability of Hedging in Relation to the Predicted Debt Ratio

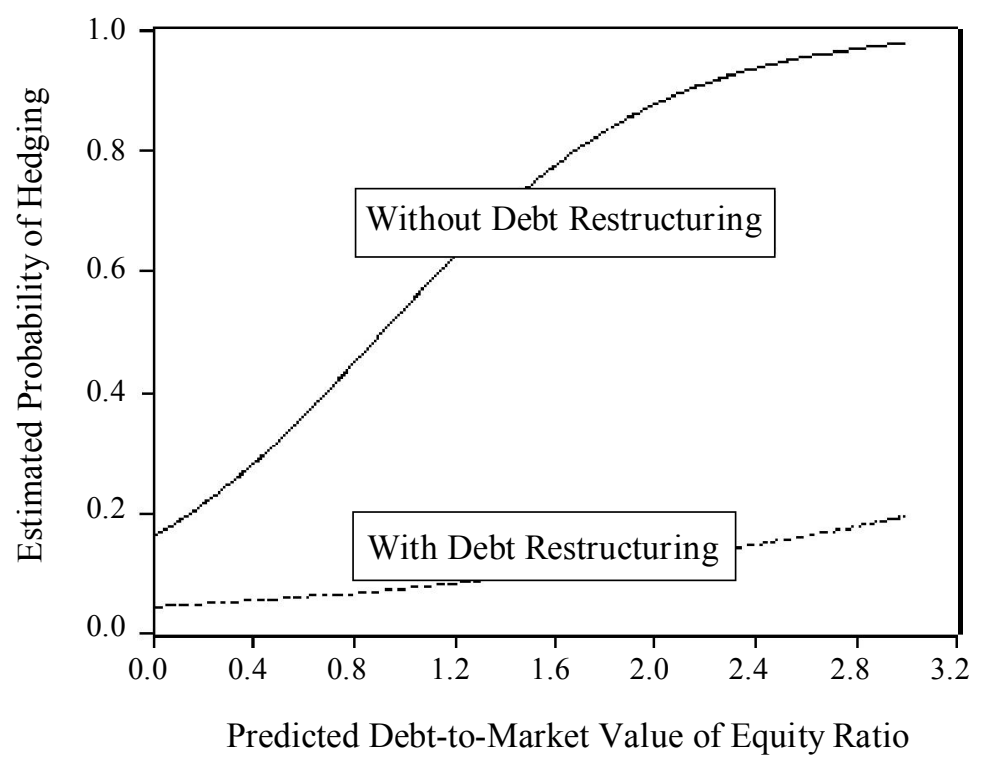


saving. Therefore, this later finding actually supports the view that distressed firms are less motivated to hedge.

The results of the Logit regression also show that corporate hedging decision is: (i) positively related with firm size (SIZE_TA), (ii) negatively related with liquid assets (LIQUID_TL) though not statistically significant, (iii) positively related with foreign exchange exposure (FCL_TA), and (iv) negatively related with debt restructuring (D_RESTRU). The estimated coefficients of the two interaction variables ( $D \_R E S T R U^{*} D E B T+M V F$ and $\left.D_{-} R E S T R U^{*} S I Z E_{-} T A\right)$ reveal that firms which debts are being restructured tend not to hedge, but large firms which debts are being restructured tend to hedge. Figure 3 shows the relationship between the probability of corporate hedging using foreign currency derivatives with the predicted value of debt ratio -with and without debt restructuring. ${ }^{18}$

Panel A of Table 4 also reports the results of the Tobit regression that has been corrected for heteroscedasticity caused by the ratio of tax-loss carry forwards-to-market value of equity (TAXLOSS). By comparing the results of both Logit and Tobit regressions, with the exceptions of two independent variables $\left(V_{-} R O A\right.$ and $\left.D_{-} R E S T R U^{*} D E B T \_M V \bar{F}\right)$, it can be said that generally the independent variables have similar impacts on the corporate hedging decision as well as on the extent of hedging. From the Logit and Tobit results, it can be seen that the volatility of earnings ( $V_{-} R O A$ ) determines firms' decision to hedge, but does not determine the notional amount of foreign currency derivatives held by firms for hedging purposes. Also, while the interaction variable D_RESTRU*DEBT_MVF significantly and negatively affects firms' decision to hedge, the same variable has a positive but not significant effect on the extent of corporate hedging using foreign currency derivatives.

Panel B of Table 4 reports the results of OLS regression for the debt policy equation. It is interesting to note that the independent variables found to have significant effects on the corporate debt policy are limited only to: (i) corporate hedging policy (D_HEDGEF and TOT_HEDGEF), (ii) firm size $\left(S I Z E_{-} T A\right),{ }^{19}$ (iii) asset tangibility $(T A N G)$, and (iv) debt restructuring (D_RESTRU). As predicted, debt levels are positively related with asset tangibility. The results also confirm that firms which debts are being restructured tend to have higher debt levels. However, the present finding that firm size is negatively related with leverage is in contradiction with previous findings (e.g. Hovakimian et

\footnotetext{
${ }^{18}$ Using mean values for other independent variables.

${ }^{19}$ However, firm size (SIZE_TA) is not statistically significant in the debt policy equation relating to the extent of hedging.
} 
Gadjah Mada International Journal of Business, May-August 2005, Vol. 7, No. 2

al. 2001). One plausible explanation is that during the periods of study-covering the periods of economic crisis- all firms tend to reduce their debt levels to avoid detrimental effects of rising interest rates. However, due to their ability to raise necessary funds to repay debt, it is argued that only larger firms that are capable of successfully reducing their debt levels. Therefore, the present study finds that larger firms tend to have lower leverage.

Of significant interest is that the results of the debt policy equation show that both the hedging decision (D_HEDGEF) and the extent of hedging using foreign currency derivatives (TOT HEDGEF) are important factors in the determination of corporate debt level (significant at $1 \%$ and $5 \%$ respectively). And since Panel $\mathrm{A}$ of Table 4 has already shown that the predicted debt level (DEBT_MVF) affects both corporate hedging decision and extent of hedging (significant at $1 \%$ for both Logit and Tobit regressions), the results of the present study have provided empirical evidence on the simultaneity of corporate hedging and debt policies. In the present study unlike those of previous results (i.e. Geczy et al. 1997; Graham and Rogers 2002), the evidence of simultaneity with the debt policy is found for both the hedging decision and the extent of hedging.

\section{Summary and Conclusion}

It is believed that many Indonesian firms employ foreign currency debts in order to exploit interest rate differentials arising from the shortterm foreign exchange market inefficiencies. However, realizing that such funding strategy would expose firms to foreign exchange rates volatility, many Indonesian firms mitigate the exposure by using foreign currency derivative instruments, such as currency forwards, futures, swaps, and options. The primary focus of the present study is to investigate the simultaneity of corporate hedging and debt policies. It is argued that firms hedge in order to reduce the probability of financial distress arising from debts; however, reduced probability of financial distress will increase firms' debt capacity and will induce them to increase their debt levels to take advantage of the tax benefits of debts. Therefore, a simultaneous relationship between corporate hedging and debt policies is hypothesized.

Using a pooled sample of Indonesian non-financial listed firms covering the periods of 1996-2001, the present study finds evidence that corporate hedging and debt policies are simultaneously determined. That is, the presence of debts motivates firms to hedge; but hedging also increases firms' debt capacity. There are also other important findings. The results of the present study show that Indonesian firms hedge in order to enhance shareholder value through reductions in financial distress and underinvest-ment costs, and alleviation of asset substitution problems. The positive relationship between firm size and corporate hedging activities 
found in this study means that -compared to those of smaller ones- larger firms are more likely to hedge. While this finding might support the contention of the existence of economies of scale in hedging costs (Nance et al. 1993; Mian 1996; Geczy et al. 1997; Graham and Rogers 2002), another plausible explanation is that larger firms may have more access to currency derivative instruments. ${ }^{20}$ Last but not least, the finding that distressed firms -as indicated by their debt restructuring programs-are less motivated to hedge is consistent with the view that levered equity is an option held by shareholders against the firm's assets where the value of debt is the exercise price. Financially distressed firms will see that the option values of their equity will increase as their cash-flow volatilities increase. Therefore, such firms tend not to hedge; or at least, hedge lesser compared to those of firms that do not experience financial distress.

\section{Limitations and Future Research}

The present study imposes two important assumptions. Firstly, it is assumed that observations are drawn fromannual random sampling, and each observation drawn is regarded as a different and independent firm. Secondly, the regression coefficients estimated in the present study are assumed to be constant over time. These two assumptions may be regarded as too restrictive. Therefore, the results of this study should be interpreted with all these restrictive assumptions in mind.

Also, data limitation and unknown potential attrition bias have prevented the present study to confidently employ a panel data approach that could provide many opportunities to explore both individual firm as well as time effects on the simultaneity of corporate hedging and debt policies. It is hoped that with more data and better financial statement disclosures, a balanced panel data approach for studying corporate hedging policy would be possible in the near future; and therefore, richer analyses and conclusions could be obtained. ${ }^{21}$

Lastly, other limitation worth mentioning is that considering the peculiarities of the Indonesian macro-economic conditions during the study periods of 1996 through 2001, the results of this study might not be extendable to periods beyond the year $2001 .{ }^{22}$ The

\footnotetext{
${ }^{20}$ Further examination reveals that large sample firms obtain currency derivative instruments through OTC markets involving some large reputable global financial institutions such as Credit Suisse First Boston, Morgan Stanley, Standard Chartered, Citibank, or Sumitomo Bank. It is doubted that smaller firms would have as equal access as their larger counterparts to such financial institutions.

${ }^{21}$ Nevertheless, the author has conducted unreported analyses where the results show that neither an unbalanced panel data approach nor relaxing the assumption of constant coefficient changes the hedging-debt simultaneity conclusion drawn by the present study.

${ }^{22}$ Due to lack of adequate financial statement disclosures, conducting a study on Indonesian firms' hedging policy prior to year 1996 would be difficult, if not impossible.
} 
Gadjah Mada International Journal of Business, May-August 2005, Vol. 7, No. 2

Rupiah exchange rates during periods subsequent to year 2001 are seen to be less volatile, and there is also a sort of widely held believe within the business community that the Rupiah currency would appreciate as the Indonesian economic and political climates start to improve. It is asserted that if firms believe that the Rupiah exchange rate would appreciate, they might opt not to hedge their currency exposures; or at least, they might selectively hedge their currency exposures. This asserted selective hedging policy should be an interesting topic for future research.

\section{References}

Allayannis, G., and J. P. Weston. 2001. The Use of Foreign Currency Derivatives and Firm Market Value. Review of Financial Studies 14 (1): 243-276.

Bessembinder, H. 1991. Forward Contracts and Firm Value: Investment Incentive and Contracting Effects. Journal of Financial and Quantitative Analysis 26 (4): 519532.

Black, F., and M. Scholes. 1973. The Pricing of Options and Corporate Liabilities. Journal of Political Economy 81: 637-654.

Breeden, D., and S. Viswanathan. 1996. Why Do Firms Hedge? An Asymmetric Information Model. Working Paper. Duke University.

Castanias, R. 1983. Bankruptcy Risk and Optimal Capital Structure. Journal of Finance 38: 1617-1635.

Culp, C. L. 2001. The Risk Management Process: Business Strategy and Tactics. John Wiley \& Sons, Inc.

DeMarzo, P., and D. Duffie. 1995. Corporate Incentives for Hedging and Hedge Accounting. Review of Financial Studies 8: 743-772.

Froot, K. A., D. S. Scharfstein, and J. C. Stein. 1993. Risk Management: Coordinating Corporate Investment and Financing Policies. Journal of Finance 48: 1629-1657.

Gay, G., and J. Nam. 1998. The Underinvestment Problem and Corporate Derivatives Use. Financial Management 27 (4): 53-69.

Geczy, C., B. A. Minton, and C. Schrand. 1997. Why Firms Use Currency Derivatives. Journal of Finance 52: 1323-1354.

Gujarati, D. N. 2003. Basic Econometrics. $4^{\text {th }}$ Edition. McGraw-Hill Higher Education.

Graham, J. R., and D. A. Rogers. 2002. Do Firms Hedge in Response to Tax Incentives? Journal of Finance 57 (2): 815-839.

Greene, W. H. 2003. LIMDEP - Version 8.0: Econometric Modeling Guide. Econometric Software, Inc.

Greene, W. H. 2002. Econometric Analysis. $5^{\text {th }}$ Edition. Prentice Hall.

Haushalter, G.D. 2000. Financing Policy, Basis Risk, and Corporate Hedging: Evidence from Oil and Gas Producers. Journal of Finance 55 (1): 107-152. 
Suriawinata-Investigating the Simultaneity ofCorporateHedging and Debt Policies

Hovakimian, A., T. Opler, and S. Titman. 2001. The Debt/Equity Choice. Journal of Financial and Quantitative Analysis 36 (1): 1-24.

Jensen, M.C. 1986. Agency Costs of Free Cash Flow, Corporate Finance and Takeovers. American Economic Review 76: 323-339.

Jensen, M.C., and W. Meckling. 1976. Theory of the Firm: Managerial Behavior, Agency Costs, and the Capital Structure. Journal of Financial Economics 3: 305360 .

Judge, G. G., R. C. Hill, W. E. Griffiths, H. Lutkepohl, and T. C. Lee. 1988. Introduction to the Theory and Practice of Econometrics. ${ }^{\text {nd }}$ Edition. John Wiley and Sons.

Leland, H. E. 1998. Agency Costs, Risk Management, and Capital Structure. Journal of Finance 53: 1213-1243.

Leland, H.E. 1994. Corporate Debt Value, Bond Covenants, and Optimal Capital Structure. Journal of Finance 49 (4): 1213-1252.

Long, J. S. 1997. Regression Models for Categorical and Limited Dependent Variables. Sage Publications.

Lookman, A. 2005. Bank Borrowing and Corporate Risk Management. Unpublished Working Paper. Tepper School of Business - Carnegie Melon University.

Mian, S.L. 1996. Evidence on Corporate Hedging Policy. Journal of Financial and Quantitative Analysis 31 (3): 419-439.

Modigliani, F., and M. Miller. 1963. Corporate Income Taxes and The Cost of Capital: A Correction. American Economic Review 53: 433-443.

Modigliani, F., and M. Miller. 1958. The Cost of Capital, Corporation Finance and the Theory of Investment. American Economic Review 48: 261-297.

Myers, S. C. 1977. Determinants of Corporate Borrowing. Journal of Financial Economics 5: 147-175.

Myers, S. C., and N. Majluf. 1984. Corporate Finance and Investment Decisions when Firms Have Information that Investors do not Have. Journal of Financial Economics 13: $187-221$.

Nance, D.R., C. W. Smith, and C. W. Smithson. 1993. On the Determinants of Corporate Hedging. Journal of Finance 48: 267-284.

Nguyen, H. and Robert Faff. 2002. On the Determinants of Derivative Usage by Australian Companies. Australian Journal of Management 27 (1): 1-24.

Ross, M. P. 1996. Corporate Hedging: What, Why and How?. Working Paper. University of California, Berkeley.

Smith, C. W., and R. Stulz. 1985. The Determinants of Firms' Hedging Policies. Journal of Financial and Quantitative Analysis 20: 391-405.

Stulz, R. 1996. Rethinking Risk Management. Journal of Applied Corporate Finance. 9: 8-24.

Stulz, R. 1990. Managerial Discretion and Optimal Financing Policies. Journal of Financial Economics 26: 3-27. 
Gadjah Mada International Journal of Business, May-August 2005, Vol. 7, No. 2

Stulz, R. 1984. Optimal Hedging Policies. Journal of Financial and Quantitative Analysis 19: $127-140$.

Suriawinata, I. S. 2004. Apakah Kebijakan Hedging Perusahaan dengan Instrumen Derivatif Valuta Asing Meningkatkan Nilai Pemegang Saham?: Bukti Empiris dari Perusahaan-Perusahaan Non-Finansial yang Terdaftar di Bursa Efek Jakarta. Prasetiya Mulya Management Journal 9 (2): 59-80.

Suriawinata, I. S. 2002. Empirical Testing of International Parity Conditions of the Rupiah Exchange Rate against the US Dollar over the Floating Rate Period. Prasetiya Mulya Management Journal 7 (13): 26-45.

Titman, S., and R. Wessels. 1988. The Determinants ofCapital Structure Choice. Journal of Finance 43: 1-18.

Tufano, P. 1996. Who Manages Risk? An Empirical Examination of Risk Management Practices in the Gold Mining Industry. Journal of Finance 51 (4): 1097-1137.

Varaiya, N., R. A. Kerin, and D. Weeks. 1987. The Relationship between Growth, Profitability, and Firm Value. Strategic Management Journal 8 (5): 487-498.

Wooldridge, J. M. 2002. Econometric Analysis of Cross Section and Panel Data. The MIT Press. 